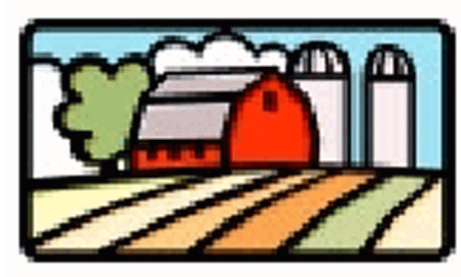

- This publication was written by Regina Fegan and Michael T. Olexa, Food and Resource Economics Department, University of Florida.

- This document, IFAS publication DH0433, was published June 1998 revised May 2003. It is part of The Disaster Handbook, a component of the Comprehensive Disaster Preparedness and Recovery Education Module; General editor: Carol J. Lehtola, Agricultural and Biological Engineering Department, Institute of Food and Agricultural Sciences, University of Florida, Gainesville, Florida 32611.

For information about products and ordering, please visit:

$<$ http://disaster.ifas.ufl.edu>.

UF/IFAS Extension publications are available at the EDIS Web site:

$<$ http://edis.ifas.ufl.edu>.

- The Institute of Food and Agricultural Sciences is an equal opportunity / affirmative action employer authorized to provide research, educational information, and other services only to individuals and institutions that function without regard to race, color, sex, age, handicap, or national origin. For information on obtaining other extension publications, contact your county Cooperative Extension Service office. Florida Cooperative Extension Service / Institute of Food and Agricultural Sciences / University of Florida / Christine Taylor Waddill, Dean.

\section{USDA Farm Service Agency Disaster Assistance}

î Where to Apply for Assistance

Ï USDA Assistance Available in Areas Designated as Natural Disaster Areas

$\bigoplus$ USDA Assistance Available in Areas Without a Major Determination of Disaster

\section{Where to Apply for Assistance}

Every county in the United States has a USDA agency office which can help citizens find the right place to apply for the assistance they need. Applications and information about emergency food assistance can be obtained at any State or local food stamp office. Find the location of your county office at:

$<$ http://offices.usda.gov/scripts/ndISAPI.dll/oip_public/USA_map $>$

For assistance for Indian tribes, first contact the nearest tribal office or the Bureau of Indian Affairs (BIA), U.S. Department of the Interior.

\section{USDA Assistance Available in Areas Designated as Natural Disaster Areas — Emergency Loans The Farm Service Agency (FSA) provides emergency loans (EM) to help cover production and physical losses in counties declared as disaster areas by the President or designated by the Secretary of Agriculture. For physical losses only, the FSA Administrator may authorize EM assistance.}

The loan limit is up to 80 percent of actual loss, with a maximum indebtedness under this program of $\$ 500,000$. 
Loans for crop, livestock, and non-real estate losses are normally repaid from 1 to 7 years depending upon the loan purpose, repayment ability, and collateral available as loan security. Loans for physical losses to real estate are normally repaid within 30 years. In unusual circumstances, repayment may be extended. The current annual interest rate is 3.75 percent.

\section{Eligibility for Loans}

o Established family farm operators

o Citizens or permanent residents of the United States

o Have the ability, training or experience to repay the loan

o Have suffered a qualifying physical loss, or a production loss of at least 30 percent in any essential farm or ranch enterprise

o Cannot obtain commercial credit

o Can provide collateral to secure an EM loan

o Receipt of application is within 8 months of the disaster designation date

o Keep acceptable farm records

o Operate in accordance with a farm plan they develop and agree to it with FSA

o May be required to participate in a financial management training program, and may be required to obtain crop insurance.

\section{Loan Uses}

o Restore or replace essential property

o Pay all or part of production costs associated with the disaster year

o Pay essential family living expenses

o Reorganize the farming operation

o Refinance debts.

\section{USDA Assistance Available in Areas without a Major Determination of Disaster}

\section{Crop Insurance}

The Risk Management Agency (RMA) was established in 1996 to administer the Federal crop insurance program and provide risk education and access to other risk management tools for producers. With the passage of the Federal Agriculture Improvement and Reform Act of 1996, producers are responsible for more of their

The Disaster Handbook

USDA Farm Service Agency Disaster Assistance

Institute of Food and Agricultural Sciences

Section 4.33

University of Florida 
agricultural risks than ever before. Crop insurance is one way producers can address their own risk management needs.

Producers must sign up for crop insurance in advance of the growing season. If you have crop insurance provided through the RMA, you can be reimbursed for unavoidable losses to your crops. When a disaster occurs, contact your insurance provider immediately to provide a "notice of loss." Your insurance provider will make the necessary arrangements to have a loss adjustor visit your farm to determine the extent of the damage and fill out the necessary paperwork.

\section{Non-Insured Crop Disaster Assistance Program (NAP)} The Non-insured Crop Disaster Assistance Program (NAP) provides assistance to reduce financial losses that occur when natural disasters cause a catastrophic loss of production or prevent planting of an eligible crop.

Eligible Crop - Eligible crops include each commercial crop or other agricultural commodity (except livestock) for which catastrophic risk protection under section 508(b) of the Federal Crop Insurance Act is not available that is produced for food or fiber. Eligible crops also include floricultural, ornamental nursery, and Christmas tree crops, turfgrass sod, and industrial crops (Federal Crop Insurance Reform and Department of Agriculture Reorganization Act of 1994, P.L. 103-354), and seed crops and aquaculture (including ornamental fish) (Federal Agriculture Improvement and Reform Act of 1996, P.L. 104-127).

Payment eligibility is based on an expected yield for the area and the producer's approved yield based on actual production history, or a transitional yield if sufficient production records are not available. Production for the applicable area expected yield of a NAP crop must be reduced by more than 35 percent because of natural disaster, and the individual producer unit must suffer greater than a 50 percent loss of yield or be prevented from planting more than 35 percent of intended acreage due to natural disaster reasonably related to the basis for the area designation.

o Beneficiaries - Eligible persons sharing in the proceeds of an eligible crop at the time of loss with annual qualifying gross revenue less than $\$ 2$ million.

o Limitations - Producer must report acreage and production by specified deadlines and furnish a timely notice of loss within 15

The Disaster Handbook Institute of Food and Agricultural Sciences University of Florida
USDA Farm Service Agency Disaster Assistance Section 4.33

Page 3 
days of the date when a loss becomes obvious. Additionally, applications for NAP payments must be filed with the local office no later than the first acreage reporting date for the crop in the crop year immediately following the crop year in which the loss occurred.

o Availability - Assistance will be made available for each approved crop in an area approved by Commodity Credit Corporation (CCC) for a natural disaster.

o Comments - No person shall receive payments for a crop year in excess of $\$ 100,000$. If a producer is eligible to receive NAP assistance and benefits under any other program administered by the Secretary for the same loss, the producer must choose whether to receive the other program benefits or NAP assistance. The producer is not eligible for both.

\section{Rural Development Assistance}

$<$ http://www.rurdev.usda.gov/ >

o Rural Business Service - Provides direct and guaranteed rural economic loans and grants and rural business enterprise grants; and offers all of its programs to businesses and cooperatives affected by natural disasters.

o Rural Housing Service - Provides subsidized direct and guaranteed loans to low-income rural residents and communities in need of housing or community facilities. Existing borrowers are offered loan forbearance, when needed, to recover from the effects of a natural disaster.

o Rural Utilities Service - Provides electric and telecommunications cooperatives and companies that are financed by the Rural Utilities Service with technical and/or loan assistance when necessary for restoration of service after a natural disaster. (These are on-going programs, not disaster assistance programs.)

\section{Food Assistance}

o Foods donated for school food service and other Food and Nutrition Service programs may be released to relief organizations that prepare congregate meal service in situations of distress.

o Additionally, the Secretary of Agriculture may authorize State/local agencies to make available disaster food stamp assistance during any disaster which disrupts commercial channels of food distribution if such assistance is determined to

The Disaster Handbook Institute of Food and Agricultural Sciences University of Florida
USDA Farm Service Agency Disaster Assistance Section 4.33

Page 4 
This publication is designed to provide accurate, current, and authoritative information on the subject. However, since the laws, regulations, administrative rulings, and court decisions on which it is based are subject to constant revision, portions of this publication could become outdated at any time. This publication is distributed with the understanding that the authors are not engaged in rendering legal advice or opinions, and the information contained herein should not be regarded, or relied upon, as a substitute for legal advice or opinion. For these reasons, the utilization of these materials by any person constitutes an agreement to hold harmless the authors, the Institute of Food and Agricultural Sciences and the University of Florida for any liability claims, damages or expenses that may be incurred by any person as a result of reference to or reliance on the information contained in this fact sheet. be necessary and commercial channels of food distribution have again been restored. Such assistance may be determined to be necessary, if, as a result of the disaster, income or resources are reduced or inaccessible, and households need food assistance that cannot be met by the regular Food Stamp Program procedures.

\section{Technical Assistance}

o Animal Diseases and Plant Pest Control - The Animal and Plant Health Inspection Service Regional Emergency Response Organizations have a network with Animal Health Officials in every State and also have their own personnel who can be detailed to advise and assist in the disaster response involving control, movement, euthanasia, and disposal of livestock and poultry. The main phone number is (301) 734-8073. Local phone numbers would be established in the event of an emergency response.

o Food Safety - The Food Safety and Inspection Service helps consumers through its toll-free meat and poultry hotline when food safety questions arise due to power failure, natural disaster, product recalls, or for other reasons. Consumers may call 1-800-535-4555, Monday through Friday, 10 a.m. to 4 p.m. Eastern Standard Time.

\section{USDA Nondiscrimination Statement}

The U. S. Department of Agriculture (USDA) prohibits discrimination in all its programs and activities on the basis of race, color, national origin, gender, religion, age, disability, political beliefs, sexual orientation, and marital or family status. (Not all prohibited bases apply to all programs.) Persons with disabilities who require alternative means for communication of program information (Braille, large print, audiotape, etc.) should contact USDA's TARGET Center at (202) 720-2600 (voice and TDD).

\section{Source for This Publication}

Natural Disaster Assistance Available from the U.S. Department of Agriculture (USDA)

U.S. Department of Agriculture (USDA)/Office of Crisis Planning and Management. Access on the Web at:

$<$ http://www.usda.gov/da/ocpm/nda.htm $>$.

The Disaster Handbook

USDA Farm Service Agency Disaster Assistance 